\title{
Perancangan Aplikasi Kasir Pada Kedai Ter_Serah.Ko Sorong
}

\author{
Ajeng Ravina Yolanda ${ }^{1}$, Matahari ${ }^{2}$, Indri Anugrah Ramadhani ${ }^{3}$ \\ Pendidikan Teknologi Informasi \\ Universitas Pendidikan Muhammadiyah Sorong \\ ajeng3472@gmail.com ${ }^{1}$, mataharitarie@gmail.com ${ }^{2}$, indianugrah18@gmail.com³
}

\begin{abstract}
Abstrak: Kedai Ter_serah.ko Sorong merupakan salah satu usaha yang bergerak di bidang penjualan minuman kekinian. Kedai Ter_serah.ko masih menggunakan sistem manual sehingga proses transaksi penjualan terhambat dan masih sering terjadi kesalahan dalam penulisan nota. Dengan masalah diatas peneliti merancang sebuah aplikasi kasir. Penelitian ini menggunakan metode $R \& D$ (Research and development) dengan menggunakan tahapan: mencari potensi dan masalah, pengumpulan data, desain produk, validasi produk, perbaikan desain, ujicoba produk, revisi produk, dan pembuatan produk masal. Selanjutnya menggunakan model waterfall dibantu dengan menggunakan bahasa pemodelan Unifield Modelling Language (UML), bahasa pemograman PHP dan MySQL sebagai pengelola database. Dengan metode ini akan mempermudah kedai ter_serah.ko dalam melalukan transaksi. Berdasarkan hasil penelitian yang telah dilakukan didapatkan hasil berupa sistem aplikasi kasir pada kedai ter_serah.ko Sorong dan buku panduan menggunakan sistem aplikasi kasir yang telah dilakukan ujicoba Black Box dan pengujian skala kecil di buktikan dengan pengujian yang melibatkan ahli dan beberapa orang sebagai user dalam skala kecil dengan aspek pemograman dengan jumlah nilai presentase 94,5\%, aspek isi 91,5\%, aspek tampilan 95\%, kelengkapan sistem 95,7\%, dan buku panduan $100 \%$.
\end{abstract}

Kata kunci: Aplikasi; e-commerce; Kasir; $R \& D$; Waterfall.

Abstract: Kedai Ter_serah.ko Sorong is one of the businesses engaged in the sale of contemporary drinks. Kedai Ter_serah.ko still uses a manual system so that the sales transaction process is hampered and there are often errors in writing notes. With the above problems, the researcher designed a cashier application. This research uses the R \& D (Research and development) method by using the following stages: searching for potentials and problems, data collection, product design, product validation, design improvement, product testing, product revision, and mass product manufacturing. Furthermore, using the waterfall model is assisted by using the Unifield Modeling Language (UML) modeling language, the PHP programming language and MySQL as database managers. This method will make it easier for the ter_serah.ko shop to carry out transactions. Based on the results of the research that has been carried out, the results are in the form of a cashier application system at the shop ter_serah.ko Sorong and a guidebook using a cashier application system that has been tested in Black Box and small-scale testing is proven by testing involving experts and several people as small scale users with programming aspects with a total percentage value of $94.5 \%$, content aspects of $91.5 \%$, display aspects of $95 \%$, completeness of systems $95.7 \%$, and $100 \%$ guidebooks.

Keywords: Application; Cashier; e-commerce; R\&D; Waterfall. 


\section{Pendahuluan}

Sejalan dengan perkembangan teknologi informasi seperti sekarang ini, sangat mudah bagi wirausahawan yang ingin mendapatkan informasi aktual dan terbuka. Oleh karena itu, banyak wirausahawan yang memanfaatkan teknologi informasi. Salah satu aspek yang perlu ditunjang oleh teknologi komputer adalah penjualan dan pelaporan barang-barang secara terkomputerisasi.

UU No 11 tahun 2008 tentang informasi dan transaksi elektronik (ITE) pada pasal 1 ayat (3) yang berbunyi "Teknologi Informasi adalah suatu teknik untuk mengumpulkan, menyiapkan, memproses, mengumumkan, menganalisis, dan atau menyebarkan informasi.Kedai ter_serah.ko merupakan kedai yang ada di kota Sorong yang menjual minuman-minuman kekinian. Kedai ter_serah.ko dikelola secara langsung oleh pemiliknya. Penjualan di Kedai Ter_serah.ko masih dengan cara manual, seperti pemesanan yang ditulis tangan dan pembayaran yang masih secara manual.

Aplikasi kasir adalah suatu aplikasi yang ditujukan untuk Kedai Ter_serah.ko yang dalam proses penulisan transaksi masih dilakukan dengan cara manual agar terhindar dari kesalahan dalam penulisan, mempersingkat waktu dalam bertransaksi yang dianggap kurang efektif dan efesien, karena sering terjadi kesalahan dalam menghitung jumlah yang harus dibayar dan banyaknya waktu yang dibutuhkan. Hasil yang ingin dicapai adalah dengan adanya aplikasi kasir pada kedai Ter_serah.ko dapat mempermudah perhitungan dalam transaksi yang dilakukan untuk meminimalisir waktu perhitungan, dan kesalahan yang terjadi dalam pembuatan struk atau nota pembayaran..

\section{Metode Penelitian}

Jenis penelitian ini menggunakan pendekatan penelitian dan pengembangan (Research and Development/ $R \& D)$. $R \& D$ merupakan metode yang sangat cocok untuk sebuah penelitian bertujuan untuk menghasilkan sebuah produk. $R \& D$ telah banyak digunakan pada penelitian bidang teknik yang menghasilkan produk teknologi. Tahap penelitian dalam perancangan sistem ini peneliti menggunakan model pengembangan waterfall. Waterfall adalah model klasik yang bersifat sistematis, berurutan dalam membangun software.

\section{Hasil dan pembahasan}

Hasil pengembangan sistem aplikasi kasir pada Kedai Ter_serah.ko Sorong dengan menggunakan metode $R \& D$ (Research and Development), yang meliputi langkah desain produk dan validasi sistem.

1. Desain produk

Desain produk dibuat berdasarkan database yang telah dibuat dalam kebutuhan sistem. Berikut ini akan dijelaksan masing-masing halaman yang dapat di akses.

a. Halaman Login

Pada halaman Login admin diminta memasukan username dan password. Jika login ini berhasil makan akan ke halaman selanjutnya namun jika proses Login mengalami kegagalan maka akan tetap berada di halaman login dapat dilihat pada Gambar 1. 


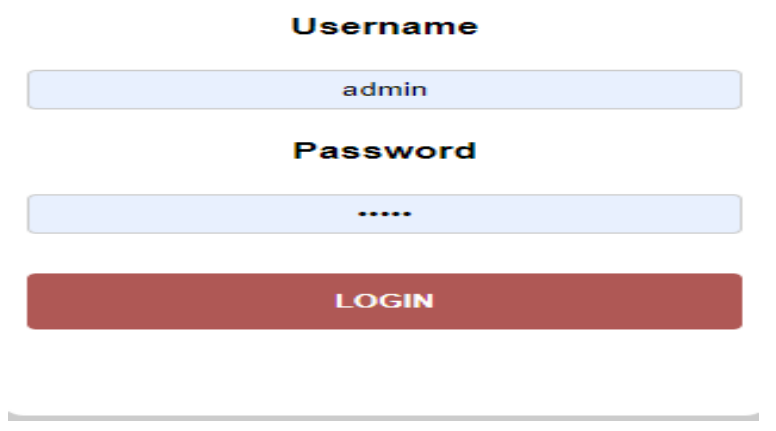

Gambar 1 Halaman Menu Login

b. Halaman menu Home

Pada halaman ini yang dapat dilihat pada Gambar 2, hanya menampilkan Logo Kedai Ter_serah.ko Sorong.

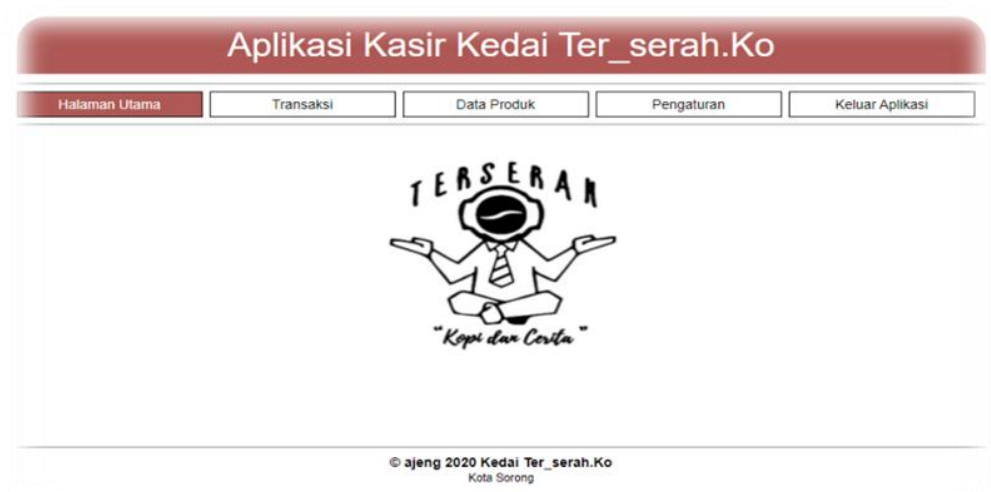

\section{Gambar 2 Halaman Menu Home}

c. Halaman menu Transaksi

Pada halaman ini dapat melakukan proses pembayaran, yang dimana terdapat nama produk, jumlah produk, harga, subtotal, batalkan transaksi dan simpan dapat dilihat pada Gambar 3.

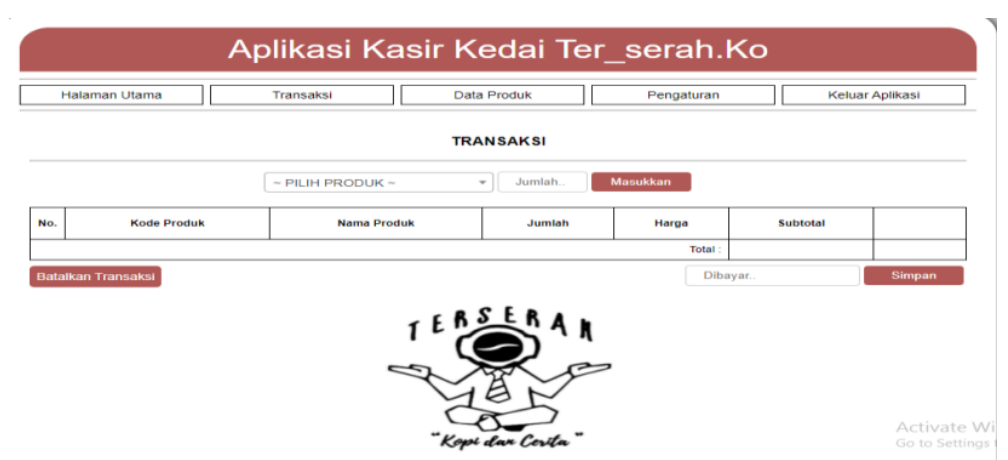

Gambar 3 Halaman Menu Transaksi 
d. Tampilan struk nota

Pada tampilan struk nota yang dapat dilihat pada Gambar 4, adalah bentuk transaksi pembayaran pada Kedai Ter_serah.ko Sorong.

\begin{tabular}{|c|c|c|}
\hline \multicolumn{3}{|c|}{$\begin{array}{l}\text { Kedai Ter_serah.Ko } \\
\text { Kota Sorong }\end{array}$} \\
\hline $2020-11-04$ & & Nota : 23 \\
\hline Taro & 20,000 & 20,000 \\
\hline Coklat Susu & 18,000 & 36,000 \\
\hline \multicolumn{2}{|r|}{ HARGA JUAL } & 56,000 \\
\hline & $\begin{array}{r}\text { TOTAL } \\
\text { BAYAR } \\
\text { KEMBALI }\end{array}$ & $\begin{array}{r}56,000 \\
100,000 \\
44,000\end{array}$ \\
\hline
\end{tabular}

\section{Gambar 4 Tampilan Nota}

\section{e. Halaman Data Produk}

Pada halaman data produk yang dapat dilihat pada Gambar 5 terdapat data-data produk minuman yang ada pada Kedai Ter_serah.ko Sorong. Di halaman ini admin dapat menambahkan produk, mengubah dan menghapus produk.

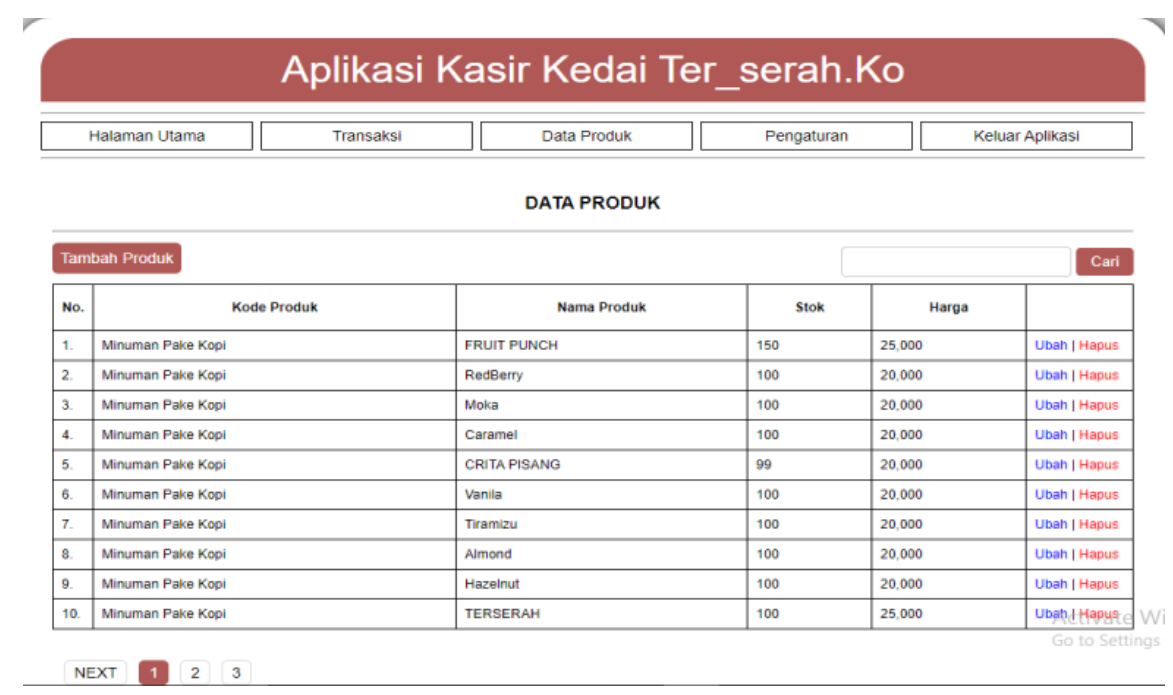

Gambar 5 halaman data Produk 
f. Halaman Pengaturan

Halaman pengaturan pada Gambar 6 untuk mengubah username, password, nama kedai, dan alamat kedai tersebut

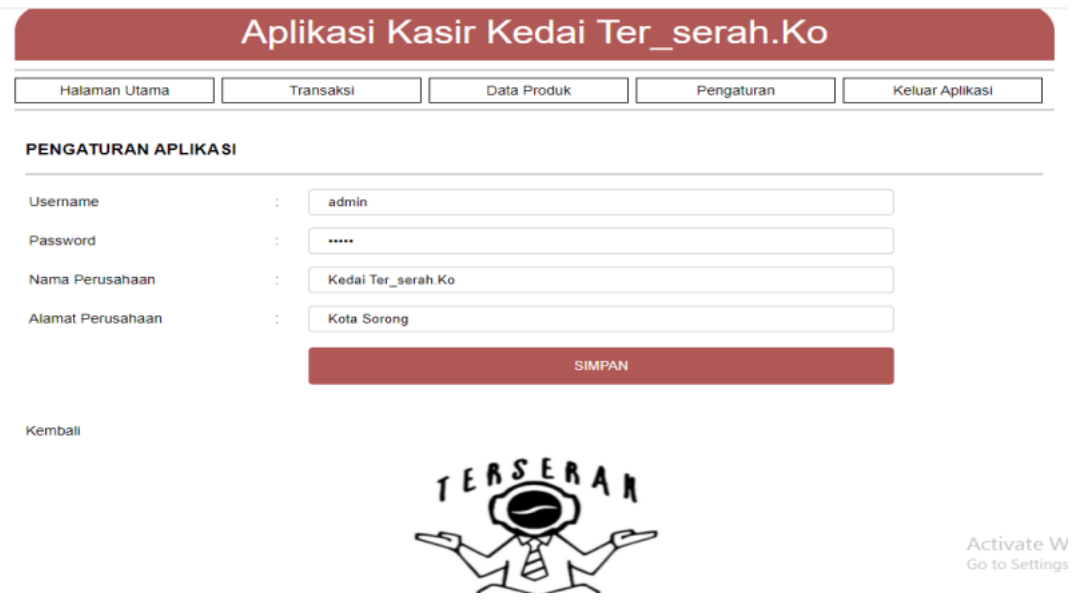

\section{Gambar 6 halaman pengaturan}

g. Halaman LogOut

Tampilan logout menampilkan tampilan awal Kedai Ter_serah.ko Sorong dapat dilihat pada Gambar 7

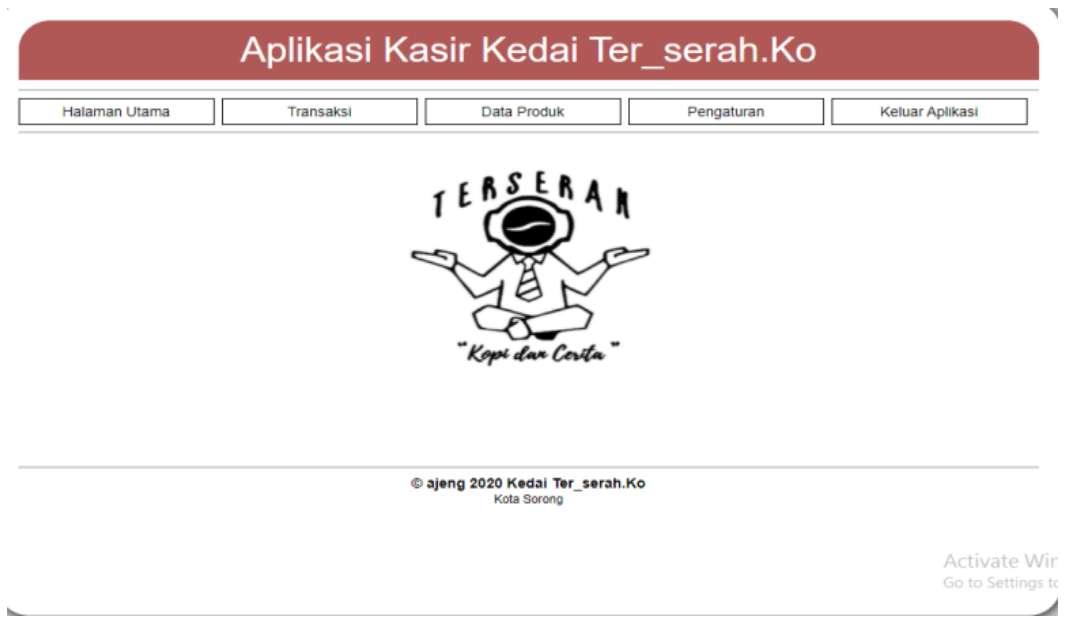

Gambar 7 Halaman LogOut

2. Uji coba kelompok kecil

Uji coba kelompok kecil dimaksudkan untuk mengetahui efesiensi perancangan aplikasi Kasir pada Kedai Ter_serah.ko Sorong dalam ruang lingkup kecil sebanyak 10 orang diantaranya pemilik Kedai Ter_serah.ko dengan mengisi angket sesuai aspek yang diminta,yang hasilnya sebagai berikut: 
a. Aspek Pemograman

Tabel 1. Uji Coba Kelompok Kecil Aspek Pemograman

\begin{tabular}{|c|c|c|c|c|}
\hline No & Indikator & $\begin{array}{l}\text { Nilai } \\
\text { Rata2 }\end{array}$ & Presentase & Keterangan \\
\hline $\mathbf{1}$ & $\begin{array}{l}\text { Kemudahan pemakaian } \\
\text { media }\end{array}$ & 4,7 & $94 \%$ & $\begin{array}{l}\text { SANGAT } \\
\text { BAIK }\end{array}$ \\
\hline 2 & $\begin{array}{l}\text { Kemudahan memilih } \\
\text { menu program }\end{array}$ & 4.9 & $98 \%$ & $\begin{array}{l}\text { SANGAT } \\
\text { BAIK }\end{array}$ \\
\hline 3 & $\begin{array}{l}\text { Kemudahan masuk dan } \\
\text { keluar dari program }\end{array}$ & 4.8 & $96 \%$ & $\begin{array}{l}\text { SANGAT } \\
\text { BAIK }\end{array}$ \\
\hline 4 & $\begin{array}{l}\text { Ketepatan reaksi tombol } \\
\text { (button) }\end{array}$ & 4.5 & $90 \%$ & $\begin{array}{l}\text { SANGAT } \\
\text { BAIK }\end{array}$ \\
\hline 5 & $\begin{array}{l}\text { Kemudahan dalam } \\
\text { melakukan transaksi }\end{array}$ & 4,7 & $94 \%$ & $\begin{array}{l}\text { SANGAT } \\
\text { BAIK }\end{array}$ \\
\hline & TOTAL & & $94,4 \%$ & $\begin{array}{l}\text { SANGAT } \\
\text { BAIK }\end{array}$ \\
\hline
\end{tabular}

Data indikator aspek pemograman yang ditunjukan pada tabel 1 menunjukan nilai rata-rata dari keseluruhan indikator 4,72 sedangkan presentase nilai 94,5\% yang artinya berada pada kategori sangat baik.

b. Aspek isi

Tabel 2. Uji Coba Kelompok Kecil Aspek Isi

\begin{tabular}{|c|c|c|c|c|}
\hline No & Indikator & $\begin{array}{l}\text { Nilai } \\
\text { Rata2 } \\
\end{array}$ & Presentase & Keterangan \\
\hline 1 & $\begin{array}{l}\text { Kejelasan bahasa yang di } \\
\text { gunakan }\end{array}$ & 4,6 & $92 \%$ & $\begin{array}{l}\text { SANGAT } \\
\text { BAIK }\end{array}$ \\
\hline 2 & $\begin{array}{l}\text { Tidak ada kata atau } \\
\text { kalimat yang menyimpang }\end{array}$ & 4.5 & $90 \%$ & $\begin{array}{l}\text { SANGAT } \\
\text { BAIK }\end{array}$ \\
\hline 3 & Kesesuaian form input & 5 & $92 \%$ & $\begin{array}{l}\text { SANGAT } \\
\text { BAIK }\end{array}$ \\
\hline 4 & Kesesuaian hasil input & 4.6 & $92 \%$ & $\begin{array}{l}\text { SANGAT } \\
\text { BAIK }\end{array}$ \\
\hline & TOTAL & 4,67 & $91,5 \%$ & $\begin{array}{l}\text { SANGAT } \\
\text { BAIK }\end{array}$ \\
\hline
\end{tabular}

Data indikator aspek isi yang ditunjukan pada tabel 2 menunjukan nilai rata-rata dari keseluruhan indikator 4,67 sedangkan presentase nilai $91,5 \%$ yang artinya berada pada kategori sangat baik. 
c. Aspek tampilan

Tabel 3 Uji Coba Kelompok Kecil Aspek Tampilan

\begin{tabular}{lllll}
\hline No & Pertanyaan & $\begin{array}{l}\text { Nilai } \\
\text { Rata2 }\end{array}$ & Presentase & Keterangan \\
\hline $\mathbf{1}$ & $\begin{array}{l}\text { Tata letak teks dan } \\
\text { gambar }\end{array}$ & 4,8 & $96 \%$ & SANGAT BAIK \\
$\mathbf{2}$ & $\begin{array}{l}\text { Kesesuaian pemilihan } \\
\text { background }\end{array}$ & 4.7 & $94 \%$ & SANGAT BAIK \\
$\mathbf{3}$ & $\begin{array}{l}\text { Kesesuaian pemilihan } \\
\text { warna tulisan }\end{array}$ & 4,8 & $96 \%$ & SANGAT BAIK \\
$\mathbf{4}$ & $\begin{array}{l}\text { Kesesuaian pemilihan } \\
\text { huruf dan jenis font }\end{array}$ & 4.6 & $92 \%$ & SANGAT BAIK \\
$\mathbf{5}$ & $\begin{array}{l}\text { Kemenenarikan hasil } \\
\text { output }\end{array}$ & 4,9 & $98 \%$ & SANGAT BAIK \\
$\mathbf{6}$ & $\begin{array}{l}\text { Kemenarikan tampilan } \\
\text { tombol }\end{array}$ & 4,7 & $94 \%$ & SANGAT BAIK \\
\hline & TOTAL & $\mathbf{4 , 7 5}$ & $\mathbf{9 5 \%}$ & SANGAT BAIK \\
\hline
\end{tabular}

Data indikator aspek tampilan yang ditunjukan pada tabel 3 menunjukan nilai rata-rata dari keseluruhan indikator 4,75 sedangkan presentase nilai 95\% yang artinya berada pada kategori sangat baik.

d. Kelengkapan sistem

Tabel 4 Uji Coba Kelompok Kecil Kelengkapan Sistem

\begin{tabular}{lllll}
\hline No & Pertanyaan & $\begin{array}{l}\text { Nilai } \\
\text { Rata2 }\end{array}$ & Presentase & Keterangan \\
\hline $\mathbf{1}$ & Header & 4,6 & $92 \%$ & SANGAT BAIK \\
$\mathbf{2}$ & Background sistem & 4.8 & $96 \%$ & SANGAT BAIK \\
$\mathbf{3}$ & Halaman login & 5 & $100 \%$ & SANGAT BAIK \\
$\mathbf{4}$ & Halaman logout & 4.9 & $98 \%$ & SANGAT BAIK \\
$\mathbf{5}$ & Halaman beranda & 4,6 & $92 \%$ & SANGAT BAIK \\
$\mathbf{6}$ & Halaman transaksi & 4,9 & $98 \%$ & SANGAT BAIK \\
$\mathbf{7}$ & Halaman data barang & 4,8 & $96 \%$ & SANGAT BAIK \\
$\mathbf{8}$ & Footer & 4,7 & $94 \%$ & SANGAT BAIK \\
$\mathbf{9}$ & Nota pembelian & 4,8 & $96 \%$ & SANGAT BAIK \\
\hline & TOTAL & $\mathbf{4 , 8}$ & $\mathbf{9 5 , 7 \%}$ & SANGAT \\
& & & & BAIK \\
\hline
\end{tabular}

Data indikator kelengkapan sistem yang ditunjukan pada tabel 4 menunjukan nilai rata-rata dari keseluruhan indikator 4,8 sedangkan presentase nilai $95,7 \%$ yang artinya berada pada kategori sangat baik. 
e. Buku panduan

Tabel 5 Uji Coba Kelompok Kecil Buku Tampilan

\begin{tabular}{lllll}
\hline No & Indikator & $\begin{array}{l}\text { Nilai } \\
\text { Rata2 }\end{array}$ & presentase & Keterangan \\
\hline $\mathbf{1}$ & $\begin{array}{l}\text { Buku petunjuk penggunaan } \\
\text { menarik dan mudah di } \\
\text { pahami }\end{array}$ & 5 & $100 \%$ & $\begin{array}{l}\text { SANGAT } \\
\text { BAIK }\end{array}$ \\
$\mathbf{2}$ & $\begin{array}{l}\text { Bahasa dalam buku panduan } \\
\text { singkat dan jelas }\end{array}$ & 5 & $100 \%$ & $\begin{array}{l}\text { SANGAT } \\
\text { BAIK } \\
\mathbf{3}\end{array}$ \\
$\begin{array}{l}\text { Buku panduan mudah di } \\
\text { gunakan }\end{array}$ & 5 & $100 \%$ & $\begin{array}{l}\text { SANGAT } \\
\text { BAIK }\end{array}$ \\
\hline & TOTAL & $\mathbf{5}$ & $\mathbf{1 0 0 \%}$ & $\begin{array}{l}\text { SANGAT } \\
\text { BAIK }\end{array}$ \\
\hline
\end{tabular}

Data indikator buku pandua yang ditunjukan pada tabel 5 menunjukan nilai ratarata dari keseluruhan indikator 5 sedangkan presentase nilai $100 \%$ yang artinya berada pada kategori sangat baik.

\section{Kesimpulan dan Saran \\ Kesimpulan}

Perancangan aplikasi kasir ini dapat mempermudah transaksi pada kedai pada Kedai Ter_serah.ko Sorong, dibuktikan dengan pengujian yang melibatkan ahli dan beberapa orang sebagai user dalam skala kecil dengan aspek pemograman dengan jumlah nilai presentase 94,5\%, aspek isi 91,5\%, aspek tampilan 95\%, kelengkapan sistem 95,7\%, dan buku panduan $100 \%$. Sistem aplikasi ini juga menghasilkan buku panduan penggunaan yang berguna untuk membantu menggunakan aplikasi kasir tersebut dibuktikan dengan uji responden dengan total rata-rata 5 dan presentase $100 \%$ kategori angat valid.

Pada sistem Aplikasi Kasir ini dalam pelaksanaan penelitian, maka penulis memberikan saran yaitu: Bagi peneliti selanjutnya yang ini merancang atau mengembangkan sistem aplikasi Kasir agar lebih kompleks dengan fitur_fitur yang belum ada dalam sistem aplikasi kasir ini. Untuk menu transaksi bisa menambahkan rekapan bulanan yang sesuai dengan kedai ter_serah.ko.

\section{Daftar Pustaka}

Apriansyah, I. M., Hidayat, A., \& Ajis, D. A. (2019). Sistem Informasi Penjualan Di Counter Fanz Cell Kota Tasikmalaya Berbasis Web. Jurnal Manajemen Informatika (Jumika), $6(2)$.

Dedi, D., Sutarman, S., \& Septiyani, N. (2020). Sistem Informasi E-Commerce Berbasis Web Pada Toko Indonesia Okubo Jepang. Academic Journal of Computer Science Research, 2(1).

Dodi Syafrizal, F. K. (2017). Sistem Informasi Orderan makanan dan booking tempat berbasis mobile android menggunakan protokol JSON. jurnal sistem informatika, 8192.

Enterprise, J. (2014). Mysql Untuk Pemula. Jakarta: PT Alex Mediakoputido

Enterprise, J. (2018). HTML, PHP, dan MySQL untuk pemula Jakarta.

Kuncoro, D. W. (2013). Analisis Dan Perancangan Sistem Kasir Dan Pendataan Stok Barang Pada Tata Distro Pacitan. Speed-Sentra Penelitian Engineering dan Edukasi, 12(1). 
M. Noval Riswandha, M. N. (2018). Rancang bangun Sistem Informasi Kasir Pada Warung "sate dan Gule bang Lukman cabang Malang". Rancang bangun Sistem Informasi Kasir, 16-22.

Muthohari, A., \& Rahayu, S. (2016). Pengembangan Aplikasi Kasir pada Sistem Informasi Rumah makan Padang Ariung. Jurnal Algoritma, 13(1), 157-163.

Noviansyah, E. (2008). Aplikasi Website Museum Nasional Menggunakan Macromedia Dreamweaver Mx. Jakarta: STIK.

Pengertian Kasir. kbbi.kemdikbud.go.id.tanggal di akses 16 februari 2020

Riswandha, M. N., \& Nadhif, M. M. (2018). Rancang Bangun Sistem Informasi Kasir Pada Warung "Sate \& Gule Bang Lukman Cabang Malang” Berbasis Web Dengan Metode Cut Off Point. Jurnal SPIRIT, 10(2).

Supono dan V. Putratama. "Pemrograman Web dengan Menggunakan PHP Framework", Yogyakarta: Depublish, Oktober 2018

Taufik, A. (2019). Perancangan Sistem Informasi Penjualan Makanan Kucing Dan Anjing Berbasis Web. Jurnal Manajemen Informatika (Jumika), 6(2).

Wisnu, G. (2016). Sistem Infromasi di Hokky Waroeng Dimsum Surakarta.

Yanto, A. B. hasta, Fauzi, A., \& Jariyah, F. A. (2018). Sistem Informasi ERecruitment

karyawan Berbasis Web Pada Pt. Jasa Swadayautama (Jayatama). Teknologi Informatika \& Komputer, 4(2), 1-6. 